\title{
The language of science and religion: An approach to understand the encounter between science and religion according to Ian G. Barbour
}

\section{Vita Fitria}

Faculty of Sharia and Law, Universitas Islam Negeri Sunan Kalijaga, Yogyakarta, Indonesia

Email: vitafitria08@gmail.com

Haekal Adha Al Giffari

Human Sciences in Communication, International Islamic University Malaysia, Selangor, Malaysia

Email:haekal.adha@gmail.com

\begin{abstract}
The advancement of science is considered a reflection of age's development. At the same time, religion is placed as a relatively fixed essence. Their encounter creates undeniable continuous tensions. The problem generally lies in the question of how to apprehend unchanged issues within a dynamic context. This paper analyzed the encounter of science and religion with an observation of their language from the perspective of Ian G. Barbour. The library research method used in this paper to delve more in-depth the works of literature related to the topic discussed. Barbour responded with an argument that it is incorrect to keep polarization to choose between science and religion. The belief system of religion offers a broader frame of meaning in life. In comparison, science reveals a no more expansive range of human experience
\end{abstract}


nor articulation of the possibility to transform human life as witnessed by religion. In observing their language as a tool for communication in religion and science, looking at their principles of verification and linguistic analysis, the contrast and comparison of their cognitive and non-cognitive function are emerged, including the evaluations and its limitations. Barbour states that basically, science and religion share synergic similarities. The dialogue to do to compare them is by sharing their similarities in method and concept prediction. One of those is by comparing their method, which shows their similarities and diversities. Science and religion share similar characteristics, namely coherence, comprehension and usefulness, and their methodology.

Keywords: Religion, Science, Ian Barbour, Language

\section{Abstrak}

Perkembangan sains bisa dianggap sebagai refleksi dari perkembangan zaman. Sementara Agama, ditempatkan sebagai essensi yang relatif tidak berubah. Pertemuan antara keduanya memungkinkan terjadinya ketegangan dengan perubahan yang terus menerus. Secara umum, persoalannya adalah bagaimana memahami hal-hal yang tak berubah itu dalam konteks yang selalu berubah. Ian Barbour menanggapi hal ini dengan argumen bahwa keliru melanggengkan dilema tentang keharusan memilih antara sains dan agama. Pertentangan yang terjadi di dunia Barat sejak abad lalu sesungguhnya disebabkan oleh paradigma yang keliru dalam memaknai hakikat sains dan agama. Kepercayaan agama menawarkan kerangka makna yang lebih luas dalam kehidupan. Sedangkan sains tidak dapat mengungkap rentang yang luas dari pengalaman manusia atau mengartikulasikan kemungkinan-kemungkinan bagi tranformasi hidup manusia sebagaimana yang dipersaksikan oleh agama. Barbour mengatakan bahwa pada dasarnya antara sains dan agama terdapat kesamaan yang bisa disinergikan. Dialog yang dilakukan dalam membandingkan sains dan agama adalah menekankan kemiripan dalam prediksi metode dan konsep. Salah satu bentuk dialognya adalah dengan membandingkan metode sains dan agama yang dapat menunjukkan kesamaan dan perbedaan. Antara sains dan agama memiliki kesejajaran karakteristik yaitu koherensi, kekomprehensifan dan kemanfaatan. Begitu juga kesejajaran metodologis.

Kata kunci: Agama, Sains, Ian Barbour, Bahasa 


\section{Introduction}

Although religion and science are both dwelling on reality in the modern thinking framework, each has a different perspective in analyzing and explaining the world (Anna, 2018). Religion and science are capable of negating each other, such as the dispute between Galileo and the catholic church about the center of the universe or the rejection of Darwin Evolution Theory by the church that emerged the high tension between both, which at the same time it was recognized the clash point between religion and science. Some scientists who espoused science's objectivity above anything negated fundamentally religious dogmatism in the same ways as religious people rejected sciences (Mahzar, 2004). Scientists identified 'reality' based on three indications of data: measurable, verifiable, and accountable. They assumed that sciences were the only source of knowledge that can be trusted and understood. At the end of the day, they were most likely to adjust the science authority to any spheres out of the sciences (Anna, 2018).

However, religion was considered subjective, exclusive, and rigid among scientists. They could not verify religion's belief due to its essence, which was not measurable, verifiable, and accountable, that contradicts the essence of science. They deemed religion as the folk stories and mythologies which had not related to sciences. Therefore, people should not believe in religion (Mahzar, 2004).

Ian Barbour $(2007,224)$ responded to this dispute and claimed that they were slip-up if they perpetuate the dilemma, forcing the urgency to espouse either religion or sciences. The clash between religion and science in western civilization occurred due to a blunder in perceiving and apprehending religion and sciences' essence. Religion offered the broader perspective of life framework. At the same time, sciences could not reveal more than human experience or articulate several possibilities of human life transformation as explained by religion.

Furthermore, Barbour said that the foundation of science and religion could be synergized by encouraging comparative dialogues to assess the similarities of the method of prediction and concept to result in similarities and differences. In connecting religion and science, this perspective was supported by Albert Einstein, who said, "Religion without Science is blind: Science without religion is lame. "Science and religion are consistent in their coherence, comprehensiveness, benefits, and methodologies. It can be understood that the conceptual and methodologies consistency lead to the possibility for interaction 
between both. The fundamental question was, 'Are there any religious traits to examine the validity of religion as what exists in science? In answering that question, this paper will focus on Barbour's ideas on the Language of Religion and the Language of Science (Barbour, 2007).

\section{The Role of Barbour in the Discourse of Religion and Science}

The advancement of science could be considered the reflection of the current development that is deemed the source of development nowadays. Meanwhile, religion was positioned as the essence that remains unchanged and rigid. Generally, the challenge was understanding the unchanged things in religion, and the relativity of science, which always changes, and the ways of science responds to religion and vice versa. To answer this challenge, it depends on understanding two concepts, namely 'essence' or the unchanged religious values and new contexts as the place or platform to operate those values, which is Science (Bagir 2005).

The news from "Newsweek" in the USA portrayed in its headline: "Science Finds God" in 1998, which was ignited numerous debates and discussions around the world as the debates between religion and science were perpetuating, especially in academic spheres. How the empirical world found God? It happened due to modern sciences' development, especially the new quantum physics development and irrationality side of Newton or Boyle (Barbour \& Muhammad, 2002). Regarding Barbour's roles in developing these spheres, scientists and religious scholars agreed that he put the foundation of the discourse related to science and religion. Although Barbour was not the first scholar who talked about the science and religion issue, his work in 1966, 'Issues in Sciences and Religion,' was well-known as he became the first scholar who did profound research with regard to this issue in terms of its matter and methodology. The book was exceptional as it juxtaposed religion and science in certain conditions without emerging the conflicts (Barbour \& Muhammad, 2002). Some numerous scientists and religionists were concerned with that issue after that book was published. They emerged many opinions and perspectives, whether in favor or against the book's ideas, which the book could not be ignored in a dwelling with regard to science and religion.

In the Islamic perspective, Muhammad Iqbal promoted 'reconstruction' of Islamic theology which he stated that the reconstruction was the methodology that opened spaces of change and adjustment, including the change and 
adjustment of science so as it will be understood easier in theological construction in accordance with the current situations (Barbour \& Muhammad, 2002). Iqbal believed that human thinking is a never-ending process without a final point. Therefore the reconstruction process will never stop. John F Haught attempted to map the conjunction between science and religion with four approaches, namely conflict approach, contact approach, contrast approach, and confirmation approach (Haught, 1995). Even though the methodology was different, but he said that Barbour had inspired his ideas.

Clayton \& Davies (2011) as a physicist believed that humans could understand God's thoughts with science. He explored the origin of the cosmos, the essence of life and consciousness, and claimed that the universe is a giant computer (Clayton \& Davies, 2011). Compared to Davies, who had drawn together between science and religion through his scientific research, Barbour was always mapping the relationship between sciences and religion and its conjunction in the historical spectrum and broadening the philosophical implication discourse. In the first chapter of 'Religion in an Age of Science,' Barbour proposed four typologies to draw out some approaches implemented in the relationship of science and religion, namely conflict, interdependence, dialogue, and integration (Graeme, 1991). In maintaining the identical classification, his typologies were modified in the revision edition in 1997 (Barbour \& For, 2007). The book entitled 'When Science Meets Religion: Enemies, Strangers, or Partners?' was published by Barbour in 2007. It talked about the examples of four mappings in terms of the relationship between science and religion.

The next chapter will focus on Barbour's thinking and methodology in bringing science and religion together based on the 'language' that had been used.

\section{The Encounter Between the Language of Science and Religion}

In response to science development and modern technology, Barbour noted that scholars and theologists attempted to directly connect science and religion, leading to less profound analysis and bias results. Scientists and theologists had forgotten the contribution of philosophy in clarifying and verifying about the issues discussed. Barbour also mentioned that mostly the relationship between philosophers and religious people or scientists was less harmonious. Their abstract statement will have a point when they meet with 
the extent of what scientists and theologists actually do in their lives (Barbour, 1972).

One of the modern philosophers' contributions in separating science and religion is related to language analysis. Language analysts directed their focus on the function of various languages used in human life. One of the characteristics function considered as religion language is an expression and reminder about worship and self-commitment as the ways of life. It is quite different from the language of science, which emphasizes prediction and control over empirical and reliable phenomena. The religious community used the 'actor' language while science community used 'observer' language. Barbour mentioned that religion and science's language was 'complementary language' (Barbour, 1972).

\section{The Principles of Verification and The Language of Religion.}

Barbour emphasized that philosophers' disputes about science and religion are only related to whether it was verifiable. The more detailed point regarding the disputes will be elaborated below:

\section{1). Empirical Data Verification}

Something that could be deemed scientific knowledge should be verifiable, which means the truth was proven empirically. This approach was claimed as the principle of positivism or the logic of positivism (Daniel, 2007). 'The principles of verification' elicited that only empirical statements can be proven as a truth by the meaningful sense experiences. The subscriber of this ideology believed that the language of religion was standardized, and all religious statements were rejected because it was considered as meaningless. Empiricism stated that the language of religion neither deviant nor truthful (Barbour, 1972). Logical positivism elaborated the meaning of 'meaningful' as an empirical statement that could be proven with the senses of experience, and it contains a formal definition, tautology, and linguistic agreements, for instance, a formal definition from an authority such as binomial nomenclature, mathematical formulas, and other formal scientific definition (Barbour, 1972). Evidence that could not be verified practically considered meaningless. Most traditional philosophic questions and all traditional metaphysics, ethics, and theology statements were deemed as not correct and not wrong, but "pseudo statement" which does not have cognitive significance (Daniel, 2007).

Several positive influences of logical positivism supported increasingly 
stringent use of language, emerging thoroughness toward metaphysical implication demands on scientific evidence, and opening an opportunity to be more self-critical (Michele, 2019). However, logical positivism was criticized to a certain degree. First, the word 'the principles of verification' cannot be verified and proven empirically. How to clarify the statement "only statements and definitions that can be verified and meaningful" was a blunder. According to Barbour, the principles of verification are deemed as a statement involved by emotions and feelings. Hence, the main principle of logical positivism is depicted as weakening its own status (Barbour, 1972). Second, an exaggerated emphasis on empirical data. It stated that scientific theory is collected by empirical data, even though it is not an absolute truth as a complicated interaction between experience and interpretation occurred. Barbour elicited that there was no scientific statement that was successfully stated as neutral observation language. Also, logical positivism oversimplifies objectivity of understanding and brings an excessive fear to subjectivity (Barbour, 1972). Third, Barbour identified that logical positivism actually implied metaphysics even though it claimed to reject metaphysics (Barbour, 1972) on how people believe what they saw and touched scientifically. In contrast, they did not think how and why it could be as such. The principles of verification eradicated all experiences, thinking, and even God's existence (Barbour, 1972).

\section{2). Linguistic Analysis}

The challenges that dealt with by the criticism of positivism emerged a new approach among philosophers. They do not use empirical verification as meaning criteria; and instead, they used a linguistic approach. The interpretation of linguistic analysis acknowledged the diversity of language and its function. The motto that dominated American and British philosophy was 'do not ask about the meaning of a statement, ask about its use' (Barbour, 1972). As cited by Barbour, J.O Urmson, a linguistic analyst in 1940, stated that language has various functions and levels to depict the world that could not be simplified in understanding it (Barbour, 1972). Wittgenstein explained similarly, which he coined a term related to language game that all sentences that were not an atomic description of a series of objects or a combination of truth-functional were indeed meaningless, as like ethical and aesthetical propositions. However, those propositions aimed to explain an important thing that means understanding language could be differentiated based on its function in the social context (Wittgenstein \& Georgallides, 2016). 
If the meaning of language is its use, then its contextuality and analysis should be dealt with by its function in accomplishing specific goals of a human being. Hence, when positivism thought about sciences by eradicating religion, the linguistic analysis considered that science and religion could be accepted by human reason, although science and religion were not related. It does not mean that each has its own truth; instead, it fulfilled its functions (Barbour, 1972).

According to linguistic analysts, the functions of the language of religion and science are very different. Barbour noted several authors' statements about the function of religion as the control of morality to shape the proper ethical behaviors (Barbour, 1972). The language of religion also functioned as to create a commitment (Ramsey, 1993) and concrete beliefs for people without questioning its validity (Zuurdeeg, 2016).

\section{Cognitive and Non-Cognitive Function in Religion}

A functional perspective of language proposed a thorough analysis regarding the activities of language communities. This approach also recommended solutions to settle the disputes between science and religion. In the perspective of linguistic analysis, science and religion were not competed and discorded because both implemented a completely different function. Barbour stated the function of the language of science is to predict and control, while the function of religion language is to worship and life orientation. Each will achieve its goals in its own ways (Barbour, 1972). This was analogized as a hammer will not be substituted by a saw due to its different function.

Looking at the different functions of science and religion, those are attributed as a non-cognitive function. Linguistic analysts acknowledged that the serious problem was the lack of cognitive function in the language of religion (Barbour, 1972). However, in some of the religious discourses, it showed several demands of reality. For example, if religious stories are deemed fiction, then the stories will gradually lose their essence as moral references. The ethical principles are always connected with the belief in the realm of reality or the context. Without the cognitive element, human commitment toward religion is fluid and never touches the intellectual dimension (Barbour, 1972). It is similar to when science stood with its cognitive principle without considering noncognitive principles; the thing that will occur was the advancement of science without ethics and awareness as a human being.

As cited by Colins, Philip Johnson in 1991 established a theory of Intelligent Design as the counter to Darwin Theory. In his book Darwin and Trial, 
Johnson noted that besides Evolution Theory cannot be proven fundamentally, and the theorist was an atheist; therefore, it was usual that the theory did not receive supports from the religious community (Collins, 2007)

According to Thomas Kuhn, concerning the revolution of Science (Kuhn, 1970), science history is considered as capable of observing various historical facts within the development of science history that contained a significant role in the subsequent development. Kuhn attempted to bridge and put the context to perceive the whole explanation's horizon, which focused on the new paradigm of science'. Kuhn stated the occurrence of changes in the sciences was not only due to empirical factors but also through the scientific revolution.' The scientific revolution was a non-cumulative development where the old paradigm substituted impartially or totally by the new paradigm that was irreconcilable by the previous one (Kuhn, 1970).

Barbour underlined his principles, whether science or religion has similarities in its dedication and willingness to understand the truth. Even though the challenges are different, both similarly stated cognitive statements and attempted to accomplish their real objectives. Whether in religion or science, critical realism is connected between empirical realism and linguistic analysis without the boundaries of empirical data or language function (Bhaskar, 2008). Realism is objective, while criticism is subjective. Barbour selected critical realism to avoid being stuck within those four categories based on the four categorical approaches. Critical realism, according to Barbour, was Inquiry concerning the "most general" categories for interpreting the structure of realities" (Barbour, 2007). Barbour cited the statement from John Wisdom that religious statements could not be clarified, but he believed that it has an objective accomplishment which means that religious statements functioned to direct human attention toward the patterns in realities. The language of religion does not only involve emotions, but religious behavior also influenced an interpretation and proposed a model to learn the patterns within the change of various experiences (Barbour, 2007). Religious discourses involved several things: directing attention toward a relationship, creating analogy, comparing alternative interpretations, recognizing patterns, and drawing out the right sides of a theistic model (Wisdom, 1969).

Disputes and tensions between religion and science, according to Ian G. Barbour, are the conflicting of connection, which is an extreme case it could be not very friendly. The separation means science and religion have their own areas without any relationship regarding their method, aspects, and goals 
without distracting and caring for one another. Dialogue is mutual respect and an open relationship because two parties would understand similarities and differences among them. Integration is the relationship based on the belief that science and religion have the same and unity in terms of study area, approach design, and objectives (Barbour, 2007).

\section{Evaluation on Religious Beliefs}

The similarities between religion and science are both patterned within trichotomic among observation, theory, and inferences. The difference lies in the study's object of study, religion focus on the meaning of life' while science observes 'causality'. Barbour mapped the process of evaluations on three aspects (Barbour, 2007):

Criteria to evaluate the religious belief. Data-oriented religious belief could be examined based on historical sources, previous interpretations, or religious experiences; Coherence, inner consistency considered as coherence that could be observed based on the relationship and implications between statements involved by the structural concept; Coverage area, religious belief is not only functioning within religious experiences but also included within personal life of subscribers.

Naturalists Interpretation on Religions. Naturalists' interpretation of evaluating religions is more likely to rationalize religions as making sense of shared human activities. For example, Feuerbach defined God based on what believers of each religion's imagination on God, which God portrayal is the same as what His followers want to portray on their mind.

The Limit of Evaluation. The influence of interpretation on experience. Religious beliefs influence evaluation criteria. Science could maintain in the same and stable situations, while social sciences can depend on established hypotheses. Further, religious science is relative based on experiences.

Intersubjective validity only can occur within a particular community. In science, the scientific community became a universal standard for communities with similar goals, standards, and procedures. While in religion, religion is a response for a certain community in which belief is examined by experience. A religious community should realize that other religious communities exist, while the scientific community stands alone;

Worldview and metaphysics system. The realistic worldview that inclusively considered encompassed all reality aspects but only depicted certain 
spheres considered a significant life reorientation framework. Besides, the metaphysics system attempts to portray comprehensive characteristics from all incidents. The system emerged from theoretical interest. However, metaphysics is not pseudoscience theory because it deals with typical characteristics of various experiences. Therefore, neither science nor religion is not under the spectrum of metaphysics.

\section{Conclusion}

Based on the explanation above, some important points need to be elaborated as the result of the researcher's interpretation of Ian Barbour's thought regarding the language of science and religion's language. First, similarities. The method attributed to science and religion is a two-sided interaction between experience and interpretation, subscribed by communities that are used referentially and realistically, the related conceptual network is evaluated coherently, and the coverage and experience to experience. Second, differences between both are the level of personal involvement is higher in religion than science, revealed knowledge in historical experience could not be compared with science, religion function is to establish commitment and exercise worship and cognitive aspect which are more likely to be ignored by linguistic analysts, an intersubjective validity of religious belief is more restricted than scientific theory, religion used more the word 'actor' while science used the term 'observer.' Third, integration according to Barbour could be achieved by starting from natural theology or theology of Nature. It has a specific meaning which aims to prove the truths of religions based on scientific evidence.

Referring to four perspectives in Barbour's typologies (conflict, independence, dialogue, and integration), he inclined to the last two, which are dialogue and integration, although there was no clear assertion whether his supports toward integration were more robust than his inclination to dialogue. Barbour discussed it as an open-minded project consisting of dialogue between two communities that respected each other's integrity. He disagreed that theology disregarded Nature; however, natural theology should contribute and protect the Nature and religion or Theology of Nature. According to Barbour, theology of Nature as the proper choice is an integration that started from a religious tradition based on religious experience and historical revealed knowledge. He argued that religious tradition should be reformulated in the current science development. 
His contributions enabled a new perspective in synthesizing the disputes between religion and science. However, in implementing his ideas, the theory will not be adequate unless it is well-grounded. Its application needs the concentration and focus of each aspect, whether subscribed religion or science development, which means that Barbour's integration theory could not be carried out without a specific methodology inclined to the particular subscribed concept of religion.

\section{References}

Anna, D. N. (2018). Metode sains menurut Ian G. Barbour dan sumbangannya terhadap pengkajian islam. Religi jurnal studi agama-agama, 14(1), 44. https://doi.org/10.14421/rejusta.2018.1401-03

Bagir, Z. A. (2005). Integrasi ilmu dan agama: Interpretasi dan aksi. Mizan Pustaka.

Barbour, I. G. (1972). Issues in science and religion. London Scm Pr.

Barbour, I. G. (2007). When science meets religion: [enemies, strangers, or partners?]. Harpersanfrancisco.

Barbour, I. G., \& For, S. (2007). Religion and science: historical and contemporary issues. International Society For Science And Religion.

Barbour, I. G., \& Muhammad, E. R. (2002). Juru bicara Tuhan antara sains dan agama. Pustaka Mizan.

Bhaskar, R. (2008). A realist theory of science. Routledge.

Braithwaite, R. B. (1977). An empiricist's view of the nature of religious belief. R. West.

Clayton, P., \& Davies, P. (2011). The re-emergence of emergence: The emergentist hypothesis from science to religion. Oxford University Press.

Collins, F. S. (2007). The language of God: A scientist presents evidence for belief. Free Press.

Daniel., D. M. (2007). Ayer's language, truth and logic. Scm Press.

Graeme, I. (1991). Religion in an age of science. Harper.

Hamzah, P. D., \& Thoha, Z. A. (2001). Membaca pikiran Tuhan: Dasar-dasar ilmiah dalam dunia yang rasional. Pustaka Pelajar.

Haught, J. F. (1995). Perjumpaan sains dan agama: Dari konflik ke dialog. Penerbit Mizan.

Kuhn, T. S. (1970). The structure of scientific revolutions. University Of Chicago 
The language of science and religion: An approach to understand ... (Vita Fitria dan Haekal Adha Al Giffari)

Press.

Mahzar, A. (2004). Revolusi integralisme Islam: merumuskan paradigma sains dan teknologi Islami. Mizan.

Michele, M. (2019). Philosophy and logical positivism. Academicus International Scientific Journal, 19, 32-36. https://doi.org/10.7336/ academicus.2019.19.02

Ramsey, I. T. (1993). Religious language. Xpress Reprints.

Wisdom, J. (1969). Philosophy and psychoanalysis. Basil Blackwell.

Wittgenstein, L., \& Georgallides, A. (2016). Tractatus logico-philosophicus. Ekdóseis Íambos.

Zuurdeeg, W. F. (2016). Analytical philosophy of religion. Routledge. 
Humanika, Kajian IImiah Mata Kuliah Umum, Vol. 21. No. 1. (2021), 55-68 